\title{
COVİD-19 Pandemisi Sürecinde Öğretim Elemanlarının Uzaktan Eğitime İlişkin Görüşlerinin Değerlendirilmesi
}

\author{
Hamiyet SAYAN, Üsküdar Üniversitesi, Sağllk Bilimleri Fakültesi, Dr. Öğr. Üyesi, \\ hamiyet.sayan@uskudar.edu.tr, (D) 0000-0001-9782-7829
}

$\ddot{O Z Z}$

Bu çalışma; örgün eğitim yapan kurumlarda Covid-19 nedeniyle, ansızın geçiş yapılan uzaktan eğitim uygulamalarının, öğretim elemanı gözüyle değerlendirilmesi amacıyla yapılmıştır. Bu amaç doğrultusunda İstanbul'daki bir devlet Ĕ̆itim Fakültesi ve bir vakıf Să̆lık Bilimleri Fakültesinde çalışan ve uzaktan eğitim yöntemiyle ders veren öğretim elemanlarının görüşleri 45 sorudan oluşan bir anket yoluyla toplanmıştır. Çalışmada, öğretim elemanlarının uzaktan eğitim uygulamalarında karşılaştıkları durumları genel anlamda belirleyerek, incelemek ve yeni uygulamalara ışık tutmak istenmektedir. Çalışma tarama modelde desenlenmiş, kesitsel tipte niceliksel olarak planlanan bir çalışmadır. Çalışmada; araştırılan konu hakkında bilgi verecek olan bireylerin ya da durumların seçildiği yöntem olan, amaçlı örneklem yöntemi kullanılmıştır. Yapılan analizler sonucunda öğretim elemanlarından elde edilen bulgular Tablolarda sunulmuş ve yorumlanmıştır. Yapılan çalışmanın özellikle uzaktan eğitime geçmeyi düşünen, yeni geçmiş olan veya zorunlu hallerde uygulamalarm etkililiğini artırmayı düşünen öğretim elemanlarına bilgi vereceği, eğitim kurumlarına yol göstereceği, bu konuda yaşanabilecek sıkıntılara yönelik önlemler almalarına katkıda bulunacă̆ı açılarından önemli görülmektedir.

Anahtar : : Uzaktan Eğitim, Çevrimiçi Öğrenme, Öğretim Elemanı, Yükseköğretim

Kelimeler

\section{Assessment of Faculty Members' Views on Distance Education During the COVID-19 Pandemic Process}

ABSTRACT

Keywords :
This work is carried out in order to evaluate the distance education applications that were suddenly switched in formal education institutions due to Covid-19 from the eyes of the instructosr. For this purpose, the opinions of the lecturers working in a state Education Faculty and a foundation Health Sciences Faculty in Istanbul and teaching by distance education were collected through a questionnaire consisting of 45 questions. In the study, it is aimed to determine and examine the situations faced by the instructors in distance education applications in general terms and to shed light on new applications. The study is a crosssectional study designed in a scanning model and planned quantitatively. Study: Purposeful sampling method, which is the method by which individuals or situations that will give information about the subject under investigation, are selected was used. As a result of the analyzes made, the findings obtained from the instructors are presented and interpreted in the Tables. The study is considered important in that it will provide information to instructors who are thinking of moving to distance education, who have just passed, or who think to increase the effectiveness of applications in compulsory situations, guide educational institutions, and contribute to taking measures against the problems that may be experienced in this regard.

Distance Education, Online Learning, Instructor, Higher Education 


\section{GİRIŞ}

Yaşadığımız zamanda bilgi teknolojileri sürekli değişmekte ve gelişmektedir. Bu gelişmeler uzaktan eğitim ile eğitim alanını da etkilemekte ve bir ihtiyaç haline gelmektedir. Aynı zamanda eğitim sorunlarını çözmede de ülkeler bilişim teknolojilerinden yararlanmaktadırlar. Bilişim teknolojileri sayesinde eğitim sistemlerinde yapısal değişikliklere gidilebilmektedir (İşman, 2011). Nitekim tüm dünyayı etkisi altına alan küresel salgın felaketi nedeniyle uzaktan eğitim Dünyada ve Türkiye' de hayatın her alanına aniden girmiş ve eğitim de dâhil bu sisteme geçilmiştir. Ancak bu geçiş beklenmedik ve ani olduğu için birtakım sorunlara neden olduğu görülmektedir.

Ülkeler için bireylerini eğitmek önemli bir sorundur. Ancak bireylere iyi bir eğitimi sağlamak; iyi plan ve uygulamaları gerektirmektedir. Bu sorun hem sayıca fazla olan bireylere eğitim vermek, hem de verilen eğitimin niteliğinin iyi olmasının sağlanması sorunudur. Bu durum yenileşmeyi gerektirmektedir. Yenileşme hareketleri ise zaman zaman dirençle karşılaşır. Ancak Covid-19 Sürecinde; eğitimdeki sorun aslında direnç gösterilmeyen, ancak hazır da olunmayan bir durumdur. İyi ki de Uzaktan Eğitim daha önceden denenmekte olan bir yol durumundadır. Aksi halde yeni yöntemler üzerinde çalışılması gerekecek ve bu da zaman kaybettirecekti. Şimdi ise sorun, uzaktan eğitimi daha etkili kullanabilme sorunudur.

Eğitimle ilgili tartışma konuları politika, donanım, hizmetin yaygınlaştırılması, sürdürülmesi, öğretmen-öğrenci oranları, bina, araç-gereç ve maliyet gibi konularda yoğunlaşsa da (Kaya, 2004), aslında temel sorunlar eğitim programlarıyla ilgilidir. Programların etkili uygulamaları ise kullanılan teknolojiyle çözülebilir görünmektedir. Türk Eğitim Sistemi'nde gerekli görülen, ancak günümüzde mecbur olunan değişim, uzaktan eğitimi yeniden ele almayı gerektirmektedir. Bu durum hem yenileşme gereğini ele almayı hem de uygulamaların programlara uygunluğunu değerlendirmeyi gerektirmektedir.

Dünyada ve Türkiye'de Uzaktan Eğitim yeni bir uygulama yöntemi değildir. Artan öğrenci sayısı, fırsat eşitliği gibi felsefe ve sorunlara çözüm amaçlı olarak, çeşitli uygulamalar zaten yürütülmekteydi. Ancak, her düzeyde ve her tür programlarda kullanılması zorunluluk haline gelince sorunlar kendiliğinden ortaya çıkmaktadır.

Yeni teknolojiler sağladıkları kolaylıklar ile öğrenme ve öğretim uygulamalarını şekillendirirler. Uzaktan eğitimin bunun en güçlü örneği olduğu söylenebilir.

Uzaktan Eğitim; öğrenen, öğreten ve öğrenme kaynakları arasındaki sınırları ortadan kaldırmaya çalışan, bunu geçekleştirebilmek için mevcut teknolojileri pragmatist bir yaklaşımla kullanan disiplinler arası bir alandır (Bozkurt, 2017). Başka bir tanımda uzaktan eğitim; en belirgin üç özelliğiyle, bilgi kaynaklarına ulaşmada ve ulaştırmada etkin bir yöntemin izlendiği, teknolojiden en iyi şekilde yararlanıldığı ve öğrenen ile öğretenin yer ve zaman olarak bağımsız olduğu bir eğitim sistemi olarak tanımlanmaktadır (Gülnar, 2008). 
Menchaca ve Bekele (2008) ise, uzaktan eğitimi; posta, telefon, internet gibi araçlar yardımıyla öğrenen ve öğretenin birbirinden uzak olduğu durumlarda öğretim faaliyetlerinin yürütülmesi şeklinde tanımlamaktadırlar. Simonson ve diğerlerine göre uzaktan eğitim, öğrenen ve öğretenin farklı ortamlarda olduğu, birbirleriyle ve kaynaklarla iletişim teknolojileri yoluyla bağlantı kurdukları, kurum bazlı yapılandırılmış formal eğitimdir (2011). Moore ve Kearsley ise uzaktan eğitimi; öğreten ve öğrenenin farklı yerlerde olduğu ve teknoloji ile iletişim kurularak özel bir kurum tarafından planlı bir şekilde tasarlanan öğrenme ve öğretme süreci olarak tanımlamaktadır (Moore ve Kearsley, 2012).

Görüldügü gibi yer ve zaman sınırlılıklarını ortadan kaldıran uzaktan eğitim, günümüzde teknolojinin gelişmesiyle birlikte daha fazla tercih edilen bir eğitim sistemi haline gelmekte iken, Covit-19 nedeniyle zorunlu bir yol olmuştur.

Tanımlardan da anlaşılacağı üzere uzaktan eğitim ve teknolojinin birbirinden ayrı düşünülmesi mümkün değildir. Dolayısıyla teknolojideki iyileşmenin uzaktan eğitimin yaygınlaşmasındaki en önemli faktör olduğu da söylenebilir. Hatta uzaktan eğitimde yapılan sinıflamalarda teknolojinin belirleyici bir rolü olduğu görülmektedir. Kullanılan teknolojiler uzaktan eğitimi dönemler halinde incelemeye fırsat vermektedir. Uzaktan Eğitim Alanı incelenince; yaygın olarak kullanılan bilgi ve iletişim teknolojilerinin belirleyici olduğu görülmektedir. Uzaktan Eğitimin tarihsel gelişim sürecine bakıldığında mektupla öğretim ile başladığı, tek yönlü radyo ve televizyon dönemi, çift yönlü radyo ve televizyon dönemi, uydu ve modern teknolojiler dönemi olarak devam ettiği görülmektedir (İşman, 2011).

Bunun yanı sıra günümüz teknolojilerinin eş zamanlı((senkron) ya da eş zamansız (asenkron) öğrenme ağları oluşturmaya olanak tanıması da teknolojinin uzaktan eğitime kattığı önemli bir üstünlük olarak görülebilir (Beldarrain, 2006). Sosyal Ağlar, İçerik Yönetim Sistemleri, Öğrenme Yönetim Sistemleri, Kitlesel Açık Çevrimiçi Kurslar (MOOCs) ve daha birçok model ya da platform şeklinde kullanılabilen sistemler bulunmaktadır. Böylece giderek yaygınlaşan uzaktan eğitimi, farklı model ve platformlarda yürütmenin yollarını aramak önemli bir çalışma alanı haline gelmiştir. Yani, uzaktan eğitimde kritik olan, sadece gelişmiş teknolojik olanaklar değil, bu teknolojilerin uygun ve planlı bir şekilde kullanılarak öğretimde kalitenin artırılmasıdır.

Bilişim tabanlı internet teknolojisiyle birlikte, eğitimde başka bir dönem yaşanmaktadır. Yükseköğretimde yer alan öğrencilerin yarısına yakını açı öğretim sisteminde bulunmaktadır. Pek çok öğretim kurumu tarafından uygulanan sistem, artık iyice yaygınlık kazanmaya başlamıştır. Hatta uzaktan eğitim düşüncesi, kavramsal olarak farklılaşmakta ve uzaktan öğrenme kavramına geçiş yapmaktadır. Artık öğretim merkezli bir anlayış yerini öğrenme merkezli bir anlayışa bırakmakta, yaşam boyu öğrenme gibi kavramı da ortaya çıkmaktadır. Artık görsel-işitsel öğrenme materyallerinin yanında, bilgisayar ve internet 
teknolojilerine dayalı öğrenme içerikleri ve materyalleri ile ortamlarının kullanılmasıyla, çift yönlü iletişim teknolojileriyle öğrenme fırsatları çeşitlenmiş ve zenginleşmiştir.

Uzaktan eğitim, tıp eğitiminden mühendisliğe, öğretmen yetiştirme ve temel bilimlere kadar birçok alanda kullanılmakta iken, günümüzde, tüm dünyada eğitimin her kademesinde ve her alanında zorunlu ve giderek daha etkili kullanıldığı görülebilmektedir (Gürer, 2018).

Uzaktan eğitimi kullanırken yararları ve sınırlılıklarının farkında olmak gerekmektedir. Uzaktan Eğitimin sağladığı olanaklar özetle belirlenirse; üniversitelerde öğretim elemanlarının iş yükünü azaltmak (Uşun, 2006: 19), öğrencilere daha iyi imkânlar sunmak, maliyeti düşürmek, eğitim kalitesini arttırmak ve hatta üniversitelerin tanınırlı̆̆ını sağlamak için kullanılmaktadır (Bolliger \& Wasilik, 2009; Menchaca \& Bekele, 2008). Ayrıca, yükseköğretimde öğrenci sayısının çok olması ve öğretim elemanı ve derslik yetersizlikleri; örgün eğitim içinde de uzaktan eğitim uygulamalarını gerekli kılmaktadır (Uşun, 2006, s. 268; Baggaley, 2008). Ancak, zorunlu olan bir durumda kullanılacak bir yol olması en önemli avantajı olarak görülebilir.

Uzaktan Eğitim avantajları yanında, pek çok açıdan sınırlılıklar da getirmektedir. Bu sınırlılıklar da öğrencilerin sosyalleşmesini sınırlandırma, kolay iletişimi sağlayamama, uygulamaya yönelik öğrenmelerdeki engellere sahip olma, kendi kendine öğrenmedeki eksiklikler, altyapı ve iletişim teknolojilerine bağımlı olmadır (Kaya, 2004). Bir diğer önemli dezavantaj ise, kurulum maliyetinin yüksek olmasıdır (Bolliger \& Wasilik, 2009; Bakioğlu \& Can, 2014: 28). Bolliger \& Wasilik (2009), internet destekli uzaktan eğitim uygulamalarında disiplin problemlerinin de yaşanabileceğini belirtmektedir.

Uzaktan Eğitimin kendisi bir öğrenme ortamı değildir, ancak öğretimin dağıtımı ve iletişim açısından kullanılan ortama bağlı bir yöntemdir. Eşzamanlı veya eşzamansız olabilmektedir. Yazılı olabildiği gibi, video, ses, grafik, simülasyonlar ve konferanslar şeklinde de olabilmektedir. Aynı şekilde, sınıf ortamının sahip olduğu olanaklara sahip olsa da araştırmalarda ortaya çıan en belirgin fark; iletişimde yüz yüze ve eşzamanlı olmayışın getirdiği devam, öğretimin tasarlanması, öğrenci motivasyonu, öğrencinin desteklenmesi, anlık iletişim ve dolaylı iletişim, izolasyon gibi öğrencilerin dile getirdiği duygulardadır. Adından anlaşıldığı gibi uzaktan eğitimde uzaklık vardır; öğretmen ve öğrencinin fiziksel olarak ayrılığı söz konusudur.

Üniversitelerde ya da diğer eğitim kurumlarında teknoloji kullanılması ile ilgili birçok olumlu taraf olmasına rağmen, teknoloji kullanımı ile ilgili birtakım sorular henüz cevaplanmış değildir. Çünkü teknolojinin ürettiği çözümler kadar birçok problemi ortaya çıkardığı da ileri sürülmektedir (Turan, 2002). Birçok eğitimci, uzaktan eğitime katılan öğrencilerin, geleneksel yüz yüze eğitim alan öğrenciler kadar öğrenip öğrenmediklerini sorgulamaktadır (Balta ve Türel, 2013). 
Uzaktan eğitimde; çevrimiçi(senkron) öğrenmeye geçildikçe ve öğretmenlerin öğrencileriyle sürekli iletişimi sağlandıkça, öğretim yönteminin içerik kadar önemli olmadığı görüşü ortaya çıkmaktadır (https://academiccontinuity.yale.edu/calendar/day/2020-04-23). Day (2015), doğal afetler, şiddet eylemleri ve pandemi tehdidi ile ilgili çalışmasında; sınıf öğretiminin iptali durumunda, ekranda öğretmeni görmenin öğrenciler üzerinde, sadece bir bilgi dosyasını görmekten farklı duygular yaşattığı sonucuna ulaşmıştır. Day, öğrenme-öğretmenin insani bir durum olduğunu ve makinaların bu yanıyla işe yaramayacağını belirtmektedir. Öğretmen ve öğrencileri kriz döneminde sonuca ulaştıracak unsur insan unsurudur, denilmektedir.

Yine salgın sırasında, yükseköğretimdeki öğrencilerin twitlerinden Prof.George Valetsianos ve Prof. Royce Kimmons; online öğrenme konusundaki ortak görüşleri belirlemeye çalışmışlardır. Onlara göre öğrenciler, sosyal katılımı, öğretmenin var olmasını, desteğini ve ilgisini, uzaktan öğretime alışkın olmalarını ve kendileriyle bağlantı kurmalarını istemektedirler (https://academiccontinuity.yale.edu/calendar/day/2020-04-23). Bu nedenle uzaktan eğitim yapan öğretmenlerin ortak alınan kararları izlemeleri, fikir birliğini önemsemeleri gerekmektedir. Sadece yüzyüze eğitimi taklit etmekten kaçınmalıdırlar. Öğretmenler kendi deneyimlerinin farkında olmalı, ayrıca profesyonel yardımlar da almalıdırlar. Online teknolojileri kullanırken öğrencileriyle birlikte yeni yollar ve denenmemiş etkinliklerde bulunmaya çalışmalıdırlar. Bu incelemede ulaşılan önemli sonuçlardan biri; bir öğretim uzmanının öğrencileriyle iletişim halinde olması kullandığı yöntemden daha önemli olduğudur.

Ama yapılanlar, uzaktan eğitimin düşünülerek yapılan tasarımları değildir. Artık pek çok öğretmenin şu anda başka seçenek olmasa da derslerini yeni bir sitemle oluşturmak için, önce olmayan zamanlarını kullanmaları ve etkili uygulamaları üretmeleri beklenmektedir. Bu durumda uzaktan eğitimi ilk defa deneyen öğretim elemanları için alandaki uzmanların profesyonel yardımları gerekmektedir.

İçerik konusunda dikkat edilmesi gerekenlerin başında, öncelikle en önemli içeriklerin belirlenip, öğrencilere ulaştırılması gelmektedir. İlerleyen zaman içinde geri kalan kısımların ele alınmasının uygun olacağı belirtilmektedir.

Diğer yandan derslerin tek bir platformda verilmesi ve çeşitli platformlara dağılmaması tavsiye edilmektedir. Yani ya sadece e-posta yolunu kullanmalı ya da gerçek zamanlı senkron uygulamalar gerçekleştirilmelidir. Yeni uygulamaları bir arada kullanmak gerekmemektedir. Öğretmenlerin öğrencileriyle sürekli iletişim halinde olması durumunda, kullanılan teknolojinin çok da önemli olmayabileceği belirtilmektedir. Önemli olan öğrenciler ile devamlı bir iletişim ve doğru seçilmiş bir içeriktir. Ancak burada da öğretmenin çıkıp içeriği okuması yerine, verilen ödevlerin üzerinde durmak, basit yönergeler sunmak ve yeni içeriği hazırlamak daha uygun olacaktır. 
Değerlendirme konusunda ise yüz yüze sınavlar yerine, bol zamanda değerlendirilebilecek ödevlere, öğrencilerin hazırlayacakları videolara, ses kayıtlarına ya da başka araçlarla oluşturulacak içeriklerle zenginleştirilmeye ihtiyaç vardır.

Ayrıca öğrencilerden canlı sunumlar veya asenkron sunumlar hazırlamaları veya öğretmenle bire bir sunum yapmaları istenebilecektir. Uygulamalı öğrenme içerikleri için; yine sanal deneyimler araştırılıp çeşitlendirilebilir. Profesyonellerle birebir bağlantılı çalışmak iyi bir yol olabilir. Örneğin; bir eğitim fakültesi öğrencisi alandan bir öğretmeni izleyebilir ve onunla; sanal ortamda öğrencileriyle nasıl çalıştığını birebir olarak deneyimleyebilir. Bir sağlık bilimleri öğrencisi de bir sağlık çalışanıyla bağlantıda olarak deneyimleri paylaşabilir.

$\mathrm{Bu}$ çalışma ile kriz durumunda; öğrenmeyi gerçekleştirecek tarafların, öğretim elemanları ve öğrenciler olduğunu düşünerek, onların sürece ilişkin duyguları görüşleri ve deneyimleri belirlenmeye çalışılmaktadır. Çalışmada, uzaktan eğitim uygulamalarının yaygın ve zorunlu olarak gerçekleştirildiği; yükseköğretim kurumlarında, Sağlık Bilimleri Fakülteleri ve Eğitim Fakülteleri gibi uygulamalı alanları içeren kurumlarda çalışan ve uzaktan öğretim yapan öğretim elemanlarının görüşleri incelenip, değerlendirilmek istenmiştir. Çalışma, mecburi ve ani bir deneyimden öğrenerek çıkmak ve keşfedilecek yeniliklerin yararlı kullanımlarının raporlanması ve paylaşılmasına yönelik olduğu için önemli görülmektedir.

\section{YÖNTEM}

Bu çalışma, Üsküdar Üniversitesi Etik Kurulunun 27.05.2020 Tarihinde yapılan 07 No'lu toplantısında verilen izin çerçevesinde yapılan bir araştırmadır.

COVID-19 Pandemisi nedeniyle eğitimde uzaktan eğitim yönteminin uygulanması zorunlu olmuştur. Bu araştırmanın amacı bu süreçte öğretim elemanlarının uzaktan eğitim faaliyetlerine yönelik görüşlerini değerlendirmektir. Bu araştırma, öğretim elemanlarının görüşlerini, deneyimlerinin; uygulamaların değerlendirilmesine yardımcı olacağı amacına yönelik olarak düzenlenmiştir.

Çalışmaya; 2019-2020 Akademik Yılı'nın, Bahar Dönemi'nde, COVID- 19 nedeniyle, uzaktan eğitim uygulamasına başlayan, İstanbul'daki biri devlet üniversitesi, eğitim fakültesi, diğeri bir vakıf üniversitesi, sağlık bilimleri fakültesinde çalışan ve uzaktan eğitim uygulamalarında ders veren 124 öğretim elemanı tamamen gönüllülük esasına dayalı olarak katılmıştır. Problemin çözümüne yönelik olarak aşağıdaki sorulara cevap aranmaktadır:

Araştırmanın temel problemi; COVID-19 Pandemisi sırasında öğretim elemanlarının uzaktan eğitim faaliyetlerine ilişkin görüşleri nelerdir?

Araştırmanın alt problemi şunlardır;

1-Cinsiyete göre öğretim elemanlarının uzaktan eğitim faaliyetlerine ilişkin görüşleri nasıldır? 
2-Yaşa göre öğretim elemanlarının uzaktan eğitim faaliyetlerine ilişkin görüşleri nasıldır?

3-Teknoloji kullanma sürelerine göre öğretim elemanlarının uzaktan eğitim faaliyetlerine ilişkin görüşleri nasıldır?

4-Alana göre öğretim elemanlarının uzaktan eğitim faaliyetlerine ilişkin görüşleri nasıldır?

5- Genel olarak uygulamalara ilişkin görüşleri nelerdir?

Araştırma kesitsel tipte, niceliksel olarak planlanan bir çalışmadır. Araştırmada veri toplama aracı olarak uzaktan eğitime ilişkin çeşitli ifadeleri içeren ve toplam beş bölümde gruplanabilen sorular ile açık uçlu sorulardan oluşan bir anket formu kullanılmıştır. Anket, araştırmacı tarafından alanyazın incelemesi ve uzman görüşlerinin alınmasıyla oluşturulmuştur. Bu bölümler, kişisel bilgiler, teknoloji kullanımı ve destek alma, derse hazırlık ve motivasyon, öğretim süreci ve değerlendirme şeklindedir. Sorular "evet- hayırkararsızım" şeklinde biçimlendirilmiş formdadır. Çalışmada; araştırılan konu hakkında bilgi verecek olan bireylerin ya da durumların seçildiği yöntem olan, amaçlı örneklem (McMillian, 1996), yöntemi kullanılmıştır. Pandeminin devam etmesi nedeniyle veriler online olarak toplanmıştır. Araştırmaya toplam 124 öğretim elemanı tamamen gönüllük esasına göre dâhil olmuştur. Elde edilen veriler SPSS programı aracılığıyla analiz edilmiştir. Tüm testlerde 0,05 hata düzeyinde anlamlılık aranmıştır.

\section{BULGULAR}

Araştırma kapsamında bulgular ilk olarak katılımcıların demografik özelliklerinin incelenmesi ile başlamıştır. Bu özelliklere ilişkin bilgiler Tablo1'deki gibidir. Burada katılımcıların yaş, cinsiyet gibi özelliklerinin yanı sıra teknoloji kullanım durumları ile ilgili de bazı bulgular yer almaktadır. İstatistiksel bilgiler kategorik değişkenler için sıklık (n) ve yüzde (\%) şeklinde, aralıklı değişkenler için ise minimum, maksimum, ortalama ve standart sapma şeklinde verilmiştir

Tablo 1. Öğretim Elemanlarının Kişisel Özelliklerinin Dağılımı

\begin{tabular}{|l|l|l|l|}
\hline \multicolumn{2}{|l|}{ Kişisel Özellikler } & Sıklık(n) & Yüzde(\%) \\
\hline \multirow{3}{*}{ Cinsiyet } & Kadın & 75 & 60,5 \\
\cline { 2 - 4 } & Erkek & 49 & 39,5 \\
\cline { 2 - 4 } & Toplam & 124 & 100,0 \\
\hline \multirow{2}{*}{ Yaş } & Min-Maks & Ortalama & Standart Sapma \\
\cline { 2 - 4 } & $(24-68)$ & 46,83 & 11,70 \\
\hline Teknoloji Kullanımı & Min-Maks (yıl) & Ortalama & Standart Sapma \\
\hline \multirow{2}{*}{ Bilgisayar Kullanımı (yıl) } & $(10-30)$ & 18,97 & 4,60 \\
\cline { 2 - 4 } & & & \\
\hline
\end{tabular}




\begin{tabular}{|c|c|c|c|}
\hline \multirow{4}{*}{$\begin{array}{l}\text { Alana Göre Uzaktan } \\
\text { Eğitimin Etkisi Değişir Mi? }\end{array}$} & & Siklik(n) & Yüzde(\%) \\
\hline & Hayır & 3 & 2,4 \\
\hline & Kararsızım & 3 & 2,4 \\
\hline & Evet & 118 & 95,2 \\
\hline \multirow{6}{*}{$\begin{array}{l}\text { Hangi Cihazla İnternete } \\
\text { Bağlanıyorsunuz? }\end{array}$} & & Siklik(n) & Yüzde(\%) \\
\hline & Bilgisayar/TelefSo & 69 & 55,6 \\
\hline & n & & \\
\hline & Bilgisayar & 25 & 20,2 \\
\hline & Telefon & 10 & 8,1 \\
\hline & $\begin{array}{l}\text { Tüm Cihazlar } \\
\text { (Tablet vs) }\end{array}$ & 20 & 16,1 \\
\hline \multirow{4}{*}{$\begin{array}{l}\text { Kullandığınız Cihazın } \\
\text { Ĕ̆itime Etkisi Var Mı? }\end{array}$} & & Siklik(n) & Yüzde(\%) \\
\hline & Hayır & 18 & 14,5 \\
\hline & Kararsızım & 7 & 5,6 \\
\hline & Evet & 99 & 79,8 \\
\hline \multirow{3}{*}{$\begin{array}{l}\text { Sizden Başka } \\
\text { Bulunduğunuz Ortamda } \\
\text { Uzaktan Eğitim Kullanan } \\
\text { Var Mi? }\end{array}$} & & Siklik(n) & Yüzde(\%) \\
\hline & Hayır & 23 & 18,5 \\
\hline & Evet & 101 & 81,5 \\
\hline \multirow{3}{*}{ Uzaktan Eğitim Şekli } & & Siklik(n) & Yüzde(\%) \\
\hline & Senkron & 77 & 62,1 \\
\hline & Asenkron & 47 & 37,9 \\
\hline \multirow{3}{*}{ Fakülte } & & Siklik(n) & Yüzde(\%) \\
\hline & Eğitim Bilimleri & 51 & 41,1 \\
\hline & Sağllk Bilimleri & 73 & 58,9 \\
\hline
\end{tabular}

Araştırmaya katılan öğretim elamanlarının demografik özellikleri ve teknoloji kullanım özellikleri yukarıdaki tabloda sunulmuştur. Buna göre araştırmaya katılan öğretim elemanlarının \%60,5'i kadın iken, \%39,5'i erkektir. Yaş ortalaması 46,83 olarak hesaplanmıştır. Öğretim elemanlarının toplam bilgisayar kullanma sürelerinin ortalaması ise 18,97 yıl olarak hesaplanmıştır. Öğretim elemanlarının neredeyse tamamı kullanılan uzaktan öğretim tekniğinin etkinliğinin bölüme göre farklı olacağını düşünmektedir $(\% 95,2)$. Ayrıca öğretim elemanlarının \%55,6'sı uzaktan öğretim için bilgisayar ve telefon kullandıklarını belirtmişlerdir. Araştırmaya katılan öğretim elemanlarının $\% 18,5^{\prime} \mathrm{i}$ ise; bu süreçte, bulundukları ortamda sadece kendilerinin uzaktan eğitim tekniğini kullandığını ifade etmişlerdir. Öğretim elemanlarının \%62'si eşzamanlı(senkron) öğretimi kullanmaktadır. Araştırmaya katılan öğretim elemanlarının \%60'1 sağlık bilimleri fakültesi öğretim 
elemanlarıdır. Araştırmada alt problem olarak cevaplanması istenen sorular pandemi sürecinde kullanılan uzaktan eğitim yönteminin; Teknoloji Kullanımı ve Destek Alma, Derse Hazırlık ve Motivasyon, Öğretim Süreci ve Değerlendirme başlıkları altında incelenmeye çalışılmıştır. Her bir başlık altında yer alan ifadeler sıklık ve yüzde üzerinden tanımlayıcı istatistikler yardımı ile incelenmiştir.

Teknoloji Kullanımı ve Destek Alma

Öğretim elemanlarının kullanılan uzaktan eğitim yönteminde teknoloji kullanımı ve destek alma süreçlerine ilişkin bulguları aşağıdaki tablodaki gibidir.

Tablo 2. Ö.E. Teknoloji Kullanımı ve Destek Alma Konusundaki Görüşleri

\begin{tabular}{|c|c|c|c|}
\hline \multirow{4}{*}{$\begin{array}{l}\text { Kullandığınız Cihazın } \\
\text { Eğitime Etkisi Var Mı? }\end{array}$} & & Siklık(N) & Yüzde(\%) \\
\hline & Hayır & 18 & 14,5 \\
\hline & Kararsızım & 7 & 5,6 \\
\hline & Evet & 99 & 79,8 \\
\hline \multirow{4}{*}{$\begin{array}{l}\text { Derslerin İşlendiği Yazılım } \\
\text { Programından Memnun } \\
\text { Musunuz? }\end{array}$} & & $\operatorname{Sikl} 1 \mathrm{k}(\mathrm{N})$ & Yüzde(\%) \\
\hline & Hayır & 17 & 13,7 \\
\hline & Kararsızım & 12 & 9,7 \\
\hline & Evet & 95 & 76,6 \\
\hline \multirow{5}{*}{$\begin{array}{l}\text { Kullanılan Programa Göre } \\
\text { Dersin Başarısı Değişir Mi? }\end{array}$} & & $\operatorname{Sikl} 1 \mathrm{k}(\mathrm{N})$ & Yüzde(\%) \\
\hline & Hayır & 13 & 10,5 \\
\hline & Kararsızım & 19 & 15,3 \\
\hline & Evet & 92 & 74,2 \\
\hline & & $\operatorname{Sikl} 1 \mathrm{k}(\mathrm{N})$ & Yüzde(\%) \\
\hline \multirow{3}{*}{$\begin{array}{l}\text { Öğretim Elemanları İçin Bir } \\
\text { Danışma Merkezine } \\
\text { İhtiyaç Duyuyor Musunuz? }\end{array}$} & Hayır & 41 & 33,1 \\
\hline & Evet & 83 & 66,9 \\
\hline & & $\operatorname{Sikl} 1 \mathrm{k}(\mathrm{N})$ & Yüzde(\%) \\
\hline \multirow{2}{*}{$\begin{array}{l}\text { Danışma Merkezi Desteği } \\
\text { Alabiliyor Musunuz? }\end{array}$} & Hayır & 30 & 24,2 \\
\hline & Evet & 94 & 75,8 \\
\hline
\end{tabular}

Tablo 2 'den anlaşıldığı gibi öğretim elemanlarının \%80'i uzaktan eğitimde kullandıkları cihazın eğitimde etkisinin var olduğunu belirtmektedir. Yine \%80'lik grup, kullanılan yazılımın etkisinin olduğunu belirtmektedir. Buna paralel olarak kullanılan yazılıma göre dersin başarısının da değişeceğini belirtenlerin oranı ise \%75 kadardır. Uzaktan eğitimde danışma merkezine ihtiyaç duyanlar ise \%67 gibi bir oran göstermektedir. Katılımcların $\% 76$ 'sı ise danışma merkezi desteğini alamadıklarını belirtmektedirler.

\section{Derse Hazırlık ve Motivasyon}


Öğretim elemanlarının uzaktan eğitim sürecinde derse hazırlık ve motivasyon süreçlerine ilişkin bulguları aşağıdaki tablodaki gibidir.

Tablo 3. Ö.E. Derse Hazırlık ve Motivasyon Konusundaki Görüşleri

\begin{tabular}{|c|c|c|c|}
\hline \multirow{4}{*}{$\begin{array}{l}\text { İnternetten Ders Vermeyi } \\
\text { Seviyor Musunuz? }\end{array}$} & & $\operatorname{Sikl1k}(\mathrm{N})$ & Yüzde(\%) \\
\hline & Hayır & 104 & 83,9 \\
\hline & Kararsızım & 20 & 16,1 \\
\hline & Evet & 0 & 0 \\
\hline \multirow{4}{*}{$\begin{array}{l}\text { Dersleri Verememekten } \\
\text { Kayg1 Duyuyor Musunuz? }\end{array}$} & & Siklık(N) & Yüzde(\%) \\
\hline & Hayır & 58 & 46,8 \\
\hline & Kararsızım & 11 & 8,9 \\
\hline & Evet & 55 & 44,4 \\
\hline \multirow{4}{*}{$\begin{array}{l}\text { Derslere Düzenli Olarak } \\
\text { Hazırlanıyor Musunuz? }\end{array}$} & & Siklik(N) & Yüzde(\%) \\
\hline & Kararsızım & 7 & 5,6 \\
\hline & Evet & 117 & 94,4 \\
\hline & & Siklık(N) & Yüzde(\%) \\
\hline \multirow{4}{*}{$\begin{array}{l}\text { Uzaktan Ĕ̆itim Derse } \\
\text { Motive Olmamı Olumlu } \\
\text { Etkiler Mi? }\end{array}$} & Hayır & 60 & 48,4 \\
\hline & Kararsizım & 29 & 23,4 \\
\hline & Evet & 35 & 28,2 \\
\hline & & $\operatorname{Sikl1k}(\mathrm{N})$ & Yüzde(\%) \\
\hline \multicolumn{2}{|c|}{ Öğrencileri Yeterince Motive|Hayır } & 58 & 46,8 \\
\hline \multirow[t]{2}{*}{ Edebiliyor Musunuz? } & Kararsızım & 35 & 28,2 \\
\hline & Evet & 31 & 25,0 \\
\hline \multirow{3}{*}{$\begin{array}{l}\text { Öğrencilerle Kolay İletişim } \\
\text { Kurabiliyor Musunuz? }\end{array}$} & Hayır & 50 & 40,3 \\
\hline & Kararsızım & 11 & 8,9 \\
\hline & Evet & 63 & 50,8 \\
\hline
\end{tabular}

Tablo 3'te görüldüğü gibi, araştırmaya katılan öğretim elemanlarının \%84'ü uzaktan eğitimle ders vermeyi sevmediklerini belirtirken, \%45'i bu yöntemle ders vermekten kayg1 duyduklarını (kararsız olanlarla birlikte, yarıya yakın oranda), tamamına yakını (\%95) ise, derse düzenli hazırlık yaptığını, \% 51'i yöntemin derse motive olmasını olumsuz etkilediğini (kararsızlarla birlikte) belirtmektedir. Öğrencileri motive edebilme konusunda ise yine olumsuz görüşler çoğunluktadır (\%75-kararsızlarla birlikte). Öğrencilerle iletişim konusunda da yarıya yakın oranda (\%49-kararsızlarla birlikte olumsuz) görüş belirtilmiştir.

\section{Öğretim Süreci}


Öğretim elemanlarının kullanılan uzaktan eğitim yönteminin öğretim süreçlerine ilişkin bulguları aşağıdaki tablodaki gibidir.

Tablo 4. Ö.E .Öğretim Sürecine İlişkin Görüşleri

\begin{tabular}{|c|c|c|c|}
\hline \multirow{4}{*}{$\begin{array}{l}\text { Derslerde Yeterince Aktif Olma } \\
\text { Firsatınız Oluyor } \mathrm{Mu} ?\end{array}$} & & Siklık(N) & Yüzde(\%) \\
\hline & Hayır & 48 & 38,7 \\
\hline & Kararsızım & 23 & 18,5 \\
\hline & Evet & 53 & 42,7 \\
\hline \multirow{4}{*}{ Ders Süreleri Yeterli Mi? } & & Siklik(N) & Yüzde(\%) \\
\hline & Hayır & 25 & 20,2 \\
\hline & Kararsızım & 3 & 2,4 \\
\hline & Evet & 96 & 77,4 \\
\hline \multirow{5}{*}{$\begin{array}{l}\text { Uzaktan Ĕ̆itimde Kullandığınız } \\
\text { Materyalleri Yeterli Buluyor } \\
\text { Musunuz? }\end{array}$} & & Siklık(N) & Yüzde(\%) \\
\hline & Hayır & 53 & 42,7 \\
\hline & Kararsızım & 22 & 17,7 \\
\hline & Evet & 49 & 39,5 \\
\hline & & Siklık(N) & Yüzde(\%) \\
\hline \multirow{3}{*}{$\begin{array}{l}\text { Daha Fazla Materyal Kullanmak } \\
\text { Gerektiğine İnaniyor Musunuz? }\end{array}$} & Hayır & 29 & 23,4 \\
\hline & Kararsızım & 15 & 12,1 \\
\hline & Evet & 80 & 64,5 \\
\hline \multirow{4}{*}{$\begin{array}{l}\text { Öğretiminizde Bilgi Dişında Eksik } \\
\text { Kalan Yanlar Olduğunu Düşünüyor } \\
\text { Musunuz? }\end{array}$} & & Siklik(N) & Yüzde(\%) \\
\hline & Hayır & 19 & 15,3 \\
\hline & Kararsızım & 32 & 25,8 \\
\hline & Evet & 73 & 58,9 \\
\hline \multirow{4}{*}{$\begin{array}{l}\text { Grup Çalışmaları, Laboratuvar Ve } \\
\text { Öğrenci Sunumları Etkili } \\
\text { Yapılabiliyor Mu? }\end{array}$} & & Siklik(N) & Yüzde(\%) \\
\hline & Hayır & 64 & 51,6 \\
\hline & Kararsızım & 31 & 25,0 \\
\hline & Evet & 29 & 23,4 \\
\hline \multirow{4}{*}{$\begin{array}{l}\text { Kameralı Derslerde Ev Ortamını } \\
\text { Paylaşmaktan Rahatsız Mısınız? }\end{array}$} & & Siklık(N) & Yüzde(\%) \\
\hline & Hayır & 72 & 58,1 \\
\hline & Kararsızım & 20 & 16,1 \\
\hline & Evet & 32 & 25,8 \\
\hline \multirow{4}{*}{$\begin{array}{l}\text { Sizce Uzaktan Eğitim Etkili Bir Yol } \\
\text { Mudur? }\end{array}$} & & Siklik(N) & Yüzde(\%) \\
\hline & Hayır & 68 & 54,8 \\
\hline & Kararsızım & 26 & 21,0 \\
\hline & Evet & 30 & 24,2 \\
\hline & & Sikl1k(N) & Yüzde(\%) \\
\hline
\end{tabular}




\begin{tabular}{|l|l|l|l|}
\hline Öğretim Elemanlarıyla Vakit & Hayır & 28 & 22,6 \\
\cline { 2 - 4 } $\begin{array}{l}\text { Geçirmek Ve Tartışmaktan Uzak } \\
\text { Kalıyor Musunuz? }\end{array}$ & Kararsızım & 10 & 8,1 \\
\cline { 2 - 4 } & Evet & 86 & 69,4 \\
\hline \multirow{2}{*}{$\begin{array}{l}\text { Bu Yöntemde Öğrencilerle } \\
\text { İletişimde Daha Rahat Olduğunuzu } \\
\text { Düşünüyor Musunuz? }\end{array}$} & & Siklık(N) & Yüzde(\%) \\
\cline { 2 - 4 } & Hayır & 91 & 73,4 \\
\cline { 2 - 4 } & Kararsızım & 7 & 5,6 \\
\cline { 2 - 4 } & Evet & 26 & 21,0 \\
\hline
\end{tabular}

Tablo 4 incelendiğinde; öğretim elemanının öğretim sürecinde yeterince aktif olmadığını düşünenlerin oranı kararsızlarla birlikte \%80'i aşmaktadır. Uzaktan eğitimin uygulamalı derslerde eksiklik yarattığı konusunda ise neredeyse tamamı aynı görüştedirler. Değerlendirme konusunda ise yine \%80 oranda olumsuz düşünmektedirler. Uzaktan eğitimle ders yapmaktan memnun olmayanların oranı da yine kararsızlarla birlikte \%76 civarındadır. Buna paralel olarak katılımcıların \%80'inden çoğu uzaktan eğitimin devam etmesini istemediklerini belirtmektedirler. Ancak sürecin kendilerini geliştireceğini düşünenlerin sayıs1 \%75 kadardır.

\section{Değerlendirme}

Öğretim elemanlarının kullanılan uzaktan eğitim yöntemini değerlendirmelerine ilişkin bulguları aşağıdaki tablodaki gibidir

Tablo 5. Ö.E. Değerlendirmeye İlişkin Görüşleri

\begin{tabular}{|c|c|c|c|}
\hline \multirow{4}{*}{$\begin{array}{l}\text { Yüz yüze Eğitimden Aldığınız } \\
\text { Verimi Aldığınızı Düşünüyor } \\
\text { Musunuz? }\end{array}$} & & Siklık(N) & Yüzde(\%) \\
\hline & Hayır & 97 & 78,2 \\
\hline & Kararsızım & 6 & 4,8 \\
\hline & Evet & 21 & 16,9 \\
\hline \multirow{3}{*}{$\begin{array}{l}\text { Uzaktan Eğitimin Uygulamalı } \\
\text { Derslerde Eksiklik Yarattığını } \\
\text { Düşünüyor Musunuz? }\end{array}$} & & Siklık(N) & Yüzde(\%) \\
\hline & Kararsızım & 7 & 5,6 \\
\hline & Evet & 117 & 94,4 \\
\hline \multirow{4}{*}{$\begin{array}{l}\text { Uzaktan Eğitimde } \\
\text { Değerlendirmenin Yapılabildiğini } \\
\text { Düşünüyor Musunuz? }\end{array}$} & & Siklık(N) & Yüzde(\%) \\
\hline & Hayır & 73 & 58,9 \\
\hline & Kararsızım & 27 & 21,8 \\
\hline & Evet & 24 & 19,4 \\
\hline \multirow{2}{*}{$\begin{array}{l}\text { Uzaktan Eğitim Yoluyla Derslerin } \\
\text { İşlenmesinden Memnun Musunuz? }\end{array}$} & & Siklik(N) & Yüzde(\%) \\
\hline & Hayır & 66 & 53,2 \\
\hline
\end{tabular}




\begin{tabular}{|c|c|c|c|}
\hline & \multicolumn{2}{|c|}{ Kararsizım 29} & \multirow{2}{*}{$\begin{array}{l}23,4 \\
23,4\end{array}$} \\
\hline & Evet & 29 & \\
\hline \multirow{4}{*}{$\begin{array}{l}\text { Uzaktan Eğitimin Devam Etmesini } \\
\text { İster Misiniz? }\end{array}$} & & Sıklık(N) & Yüzde(\%) \\
\hline & Hayır & 92 & 74,2 \\
\hline & Kararsızım & 10 & 8,1 \\
\hline & Evet & 22 & 17,7 \\
\hline \multirow{4}{*}{$\begin{array}{l}\text { Uzaktan Eğitimde Kendinizi } \\
\text { Geliştireceğinizi Düşünür } \\
\text { Müsünüz? }\end{array}$} & & Siklik(N) & Yüzde(\%) \\
\hline & Hayır & 42 & 33,9 \\
\hline & Kararsızım & 24 & 19,4 \\
\hline & Evet & 58 & 46,8 \\
\hline
\end{tabular}

Tablo $5^{\prime}$ ten anlaşılabileceği gibi, öğretim elemanlarının \%80 den fazlası yüz yüze eğitimden aldıkları verimi alamadıklarını, neredeyse tamamı uygulamalı derslerde uzaktan eğitimin etkili olmadığını düşünmektedirler. \%80 oranında (kararsızlarla birlikte), uzaktan eğitimde değerlendirmenin yapılamayacağını belirtmektedirler. Derslerin uzaktan eğitim yöntemiyle işlenmesinden memnun olmadıklarını belirtenlerin oranı ise \%80'dir. Uzaktan eğitimin devam etmesini istemeyenlerin oranı \%83, uzaktan eğitimle kendilerini geliştirdiklerini düşünenlerin oranı ise \%67' dir. Uzaktan eğitimden memnun değiller, devam etmesini istememekle birlikte, bu yöntemin kendilerini geliştirdiğini düşünenler ise \%47 orana sahiptir.

Öğretim Elemanlarının Çeşitli Özellikleri ile Uzaktan Eğitimi Değerlendirmeleri Arasındaki İlişkilere Ait Bulgular

$\mathrm{Bu}$ bölümde araştırmaya katılan öğretim elemanlarının cinsiyet, yaş, fakülte ve bilgisayar kullanım süresi gibi gruplanan özellikleri ile uzaktan eğitim yöntemine ilişkin görüşleri arasındaki ilişki incelenmiştir. Uzaktan eğitim değerlendirmelerinde her bir boyut kendi içinde hesaplanmıştır. İfadeler içinde negatif anlama gelenler ters çevrilerek yeniden kodlanmıştır. İlgili puanın yükselmesi uzaktan eğitim sürecinin etkisinin arttığını göstermektedir. İkili grupların puanlarının karşılaştırılmasında Mann Whitney U testi kullanılmıştır. Bu testin tercih edilme nedeni, veri setinin normal dağılım göstermemesidir. Bu test sürekli değişkenlere sahip gruplar arasında karşılaştırma yapmayı sağlar. Değerler sıralı hale çevrilir ve her grup için sıralı ortalamalar karşılaştırılır (Kalaycı, 2014).

Tablo 6. Ö.E.Cinsiyet Değişkeni İle Uzaktan Eğitimi Değerlendirmeleri Arasındaki İlişki

\begin{tabular}{|c|c|c|c|}
\hline \multicolumn{3}{|l|}{ Mann Whitney U Testi } & \multirow{3}{*}{ Olasılık Değeri $(p)$} \\
\hline \begin{tabular}{|l|l|} 
& Cinsiyet $\mathbb{N}$
\end{tabular} & Sira Değer & $\mathrm{U}$ & \\
\hline & Ortalaması & $\begin{array}{l}\text { Test } \\
\text { İstatistiği }\end{array}$ & \\
\hline
\end{tabular}




\begin{tabular}{|c|c|c|c|c|c|}
\hline \multirow{3}{*}{ TKDA } & Kadin & 75 & 71,08 & \multirow{3}{*}{1194,000} & \multirow[t]{3}{*}{001} \\
\hline & Erkek & 49 & 49,37 & & \\
\hline & Toplam & 124 & & & \\
\hline \multirow{3}{*}{ DHM } & Kadin & 75 & 57,01 & \multirow{3}{*}{1425,500} & \multirow[t]{3}{*}{033} \\
\hline & Erkek & 49 & 70,91 & & \\
\hline & Toplam & 124 & & & \\
\hline \multirow{3}{*}{ ÖS } & Kadin & 75 & 61,05 & \multirow{3}{*}{1729,000} & \multirow[t]{3}{*}{576} \\
\hline & Erkek & 49 & 64,71 & & \\
\hline & Toplam & 124 & & & \\
\hline \multirow{3}{*}{ DEG } & Kadin & 75 & 64,44 & \multirow{3}{*}{1692,000} & \multirow[t]{3}{*}{445} \\
\hline & Erkek & 49 & 59,53 & & \\
\hline & Toplam & 124 & & & \\
\hline
\end{tabular}

TDA: Teknoloji Kullanımı ve Destek Alma, DHM: Derse Hazırlık ve Motivasyon, ÖS:

Öğretim Süreci, DEG: Değerlendirme, U: Mann Whitney U Testi,

Tablo 6'da Teknoloji Kullanımı ve Destek Alma, Derse Hazırlık ve Motivasyon, Öğretim Süreci, Değerlendirme açısından uzaktan eğitim sürecinin değerlendirilmesi cinsiyete göre karşılaştıılmalı olarak sunulmuştur. Tabloya göre kadın ve erkek öğretim üyelerinin, uzaktan eğitimi, teknoloji kullanımı ve destek alma açısından değerlendirmeleri arasında Mann Whitney U testine göre istatistiksel olarak anlamlı farklılık tespit edilmiştir $(p<0,05)$. Kadın öğretim üyelerinin erkek öğretim üyelerine göre bu süreçten Teknoloji Kullanımı ve Destek Alma açısından daha fazla etkilendiklerini düşündükleri söylenebilir. Diğer taraftan kadın ve erkek öğretim elemanlarının, uzaktan eğitimde derse hazırlık ve motivasyon açısından değerlendirmeleri arasında Mann Whitney U testine göre istatistiksel olarak yine anlamlı farklılık tespit edilmiştir. Erkek öğretim üyelerinin kadın öğretim üyelerine göre; derse hazırlık ve motivasyon açısından daha fazla etkilendiklerini düşündükleri söylenebilir. Öğretim Süreci ve Değerlendirme açısından ise uzaktan eğitim sürecinin değerlendirilmesi cinsiyete göre anlamlı şekilde farklılaşmamaktadır. Kadın ve erkek öğretim üyelerinin puan ortalamaları birbirine yakın hesaplanmıştır $(p>0,05)$.

Tablo 7. Ö.E. Yaş Değişkeni ile Uzaktan Eğitimi Değerlendirmeleri Arasındaki İlişki

\begin{tabular}{|l|l|l|l|l|l|}
\hline \multicolumn{4}{|l|}{ Mann Whitney U Testi } & \\
\hline \multirow{2}{*}{} & Yaş Grubu & N & $\begin{array}{l}\text { Sira Değer } \\
\text { Ortalaması }\end{array}$ & Test İstatistiği & $\begin{array}{l}\text { Olasılık } \\
\text { Değeri (p) }\end{array}$ \\
\hline \multirow{2}{*}{ TKDA } & 40 yaş altı & 32 & 78,86 & 948,500 &, 002 \\
\cline { 2 - 6 } & 41 yaş ve üstü & 92 & 56,81 & \\
\hline
\end{tabular}




\begin{tabular}{|c|c|c|c|c|c|}
\hline & Toplam & 124 & & & \\
\hline \multirow{3}{*}{ DHM } & 40 yaş altı & 32 & 55,27 & \multirow{3}{*}{1240,500} & \multirow[t]{3}{*}{181} \\
\hline & 41 yaş ve üstü & 92 & 65,02 & & \\
\hline & Toplam & 124 & & & \\
\hline \multirow{3}{*}{ ÖS } & 40 yaş altı & 32 & 48,53 & \multirow{3}{*}{1025,000} & \multirow[t]{3}{*}{,010 } \\
\hline & 41 yaş ve üstü & 92 & 67,36 & & \\
\hline & Toplam & 124 & & & \\
\hline \multirow{3}{*}{ DEG } & 40 yaş altı & 32 & 54,45 & \multirow{3}{*}{1214,500} & \multirow[t]{3}{*}{, 131} \\
\hline & 41 yaş ve üstü & 92 & 65,30 & & \\
\hline & Toplam & 124 & & & \\
\hline
\end{tabular}

Tablo 7'de Teknoloji Kullanımı ve Destek Alma, Derse Hazırlık ve Motivasyon, Öğretim Süreci, Değerlendirme açısından uzaktan eğitim sürecinin değerlendirilmesi yaşa göre karşılaştırılmalı olarak sunulmuştur. Tabloya göre 40 yaş altı ve 40 yaş üstü öğretim üyelerinin, uzaktan eğitimi, teknoloji kullanımı ve destek alma açısından değerlendirmeleri arasında Mann Whitney $U$ testine göre istatistiksel olarak anlamlı farklılık tespit edilmiştir $(p<0,05) .40$ yaş altı öğretim üyelerinin 40 yaş üstü öğretim üyelerine göre bu sürecin Teknoloji Kullanımı ve Destek Alma konusundaki sorulan yanların eğitimi daha fazla etkileyeceğini düşünmektedirler. Diğer taraftan 40 yaş altı ve öğretim elemanlarının, uzaktan eğitimi öğretim süreci açısından değerlendirmeleri arasında Mann Whitney U testine göre istatistiksel olarak yine anlamlı farklılık tespit edilmiştir $(p<0,05)$. 40 yaş üstü öğretim üyelerinin 40 yaş altı öğretim üyelerine göre; uzaktan eğitimdeki süreçlerin öğretimi daha fazla etkileyeceğini düşünmektedirler. Derse Hazırlık ve Motivasyon, ile Değerlendirme açısından ise uzaktan eğitim sürecinin değerlendirilmesi yaşa göre anlamlı şekilde farklılaşmamaktadır. 40 yaş altı ve üstü öğretim üyelerinin puan ortalamaları birbirine yakın hesaplanmıştır $(p>0,05)$.

Tablo 8. Ö.E. Fakülte Değişkeni İle Uzaktan Eğitimi Değerlendirmeleri Arasındaki İlişki

\begin{tabular}{|c|c|c|c|c|c|}
\hline \multicolumn{5}{|c|}{ Mann Whitney U Testi } & \multirow{3}{*}{$\begin{array}{l}\text { Olasılık } \\
\text { Değeri (p) }\end{array}$} \\
\hline & Fakülte & $\mathrm{N}$ & Sira Değer & \multirow[t]{2}{*}{ Test İstatistiği } & \\
\hline & & & Ortalaması & & \\
\hline \multirow{3}{*}{ TKDA } & Eğitim Bilimleri & 51 & 59,84 & \multirow{3}{*}{1726,000} & \multirow[t]{3}{*}{478} \\
\hline & Sağlık Bilimleri & 73 & 64,36 & & \\
\hline & Toplam & 124 & & & \\
\hline \multirow{3}{*}{ DHM } & Eğitim Bilimleri & 51 & 48,04 & \multirow{3}{*}{1124,000} & \multirow[t]{3}{*}{,000 } \\
\hline & Sağlık Bilimleri & 73 & 72,60 & & \\
\hline & Toplam & 124 & & & \\
\hline
\end{tabular}




\begin{tabular}{|c|c|c|c|c|c|}
\hline \multirow{3}{*}{ ÖS } & Eğitim Bilimleri & 51 & 51,21 & \multirow{3}{*}{1285,500} & \multirow[t]{3}{*}{003} \\
\hline & \multicolumn{2}{|c|}{ Sağlık Bilimleri 73} & 70,39 & & \\
\hline & Toplam & 124 & & & \\
\hline \multirow{3}{*}{ DEG } & Eğitim Bilimleri & 51 & 68,06 & \multirow{3}{*}{1578,000} & \multirow[t]{3}{*}{139} \\
\hline & Sağlık Bilimleri & 73 & 58,62 & & \\
\hline & Toplam & 124 & & & \\
\hline
\end{tabular}

Tablo 8'de Teknoloji Kullanımı ve Destek Alma, Derse Hazırlık ve Motivasyon, Öğretim Süreci, Değerlendirme açısından uzaktan eğitim sürecinin değerlendirilmesi fakülteye göre karşılaştırılmalı olarak sunulmuştur. Tabloya göre eğitim bilimleri ve sağlık bilimleri öğretim üyelerinin, uzaktan eğitimi, Derse Hazırlık ve Motivasyon ve Öğretim Süreci değerlendirmeleri arasında Mann Whitney U testine göre istatistiksel olarak anlamlı farklılık tespit edilmiştir $(p<0,05)$. Sağlık Bilimleri Fakültesi öğretim üyelerinin Eğitim Fakültesi öğretim üyelerine göre uzaktan eğitimin, Derse Hazırlık ve Motivasyon süreçlerinden daha fazla etkileneceğini düşünmektedirler. Diğer taraftan Eğitim Bilimleri ve Sağlık Bilimleri öğretim elemanlarının, uzaktan eğitimi, öğretim süreçleri açısından değerlendirmeleri arasında Mann Whitney $U$ testine göre istatistiksel olarak yine anlamlı farklılık tespit edilmiştir $(p<0,05)$. Sağlık bilimleri fakültesi öğretim üyelerinin, eğitim bilimleri fakültesi öğretim üyelerine göre öğretim süreçleri açısından daha fazla etkilendiklerini düşündükleri söylenebilir. Teknoloji Kullanımı ve Destek Alma ve Değerlendirme açısından ise uzaktan eğitim sürecinin değerlendirilmesi yaşa göre anlamlı şekilde farklılaşmamaktadır. Sağlık Bilimleri ve Eğitim Bilimleri öğretim üyelerinin puan ortalamaları birbirine yakın bulunmuştur ( $p>0,05)$.

Tablo 9. Ö.E .Bilgisayar Kullanma Süresi İle Uzaktan Eğitimi Değerlendirmeleri Arasındaki İlişki

\begin{tabular}{|c|c|c|c|c|c|}
\hline \multicolumn{5}{|c|}{ Mann Whitney U Testi } & \multirow[b]{2}{*}{ Olasılık } \\
\hline & Bilgisayar & $\mathrm{N}$ & Sira Değer & Test İstatistiği & \\
\hline & Kullanım Süresi & & Ortalamas 1 & & Değeri $(p)$ \\
\hline \multirow{3}{*}{ TKDA } & 10 yil ve altı & 8 & 79,31 & \multirow{3}{*}{329,500} & \multirow[t]{3}{*}{158} \\
\hline & 10 yıl ve üstü & 116 & 61,34 & & \\
\hline & Toplam & 124 & & & \\
\hline \multirow{3}{*}{ DHM } & 10 yıl ve altı & 8 & 45,94 & \multirow{3}{*}{331,500} & \multirow[t]{3}{*}{173} \\
\hline & 10 yıl ve üstü & 116 & 63,64 & & \\
\hline & Toplam & 124 & & & \\
\hline \multirow{3}{*}{ ÖS } & 10 yıl ve altı & 8 & 23,75 & \multirow{3}{*}{154,000} & \multirow[t]{3}{*}{,001 } \\
\hline & 10 yll ve üstü & 116 & 65,17 & & \\
\hline & Toplam & 124 & & & \\
\hline
\end{tabular}




\begin{tabular}{|l|l|l|l|l|l|}
\hline \multirow{2}{*}{ DEG } & 10 yıl ve altı & 8 & 25,00 & & \multirow{2}{*}{, 002} \\
\cline { 2 - 4 } & 10 yıl ve üstü & 116 & 65,09 & 164,000 & \\
\cline { 2 - 4 } & Toplam & 124 & & & \\
\hline
\end{tabular}

Tablo 9'da Teknoloji Kullanımı ve Destek Alma, Derse Hazırlık ve Motivasyon, Öğretim Süreci, Değerlendirme açısından uzaktan eğitim sürecinin değerlendirilmesi bilgisayar kullanma sürelerine göre karşılaştırılmalı olarak sunulmuştur. Tabloya göre 10 yıl üstü ve altı sürede bilgisayar kullanan öğretim üyelerinin; uzaktan eğitimin, Öğretim Süreci ve Değerlendirme açısından Mann Whitney U testine göre istatistiksel olarak anlamlı farklılık tespit edilmiştir $(p<0,05) .10$ yıldan fazla bilgisayar kullanan öğretim üyelerinin diğer öğretim üyelerine göre uzaktan eğitimin; Öğretim Süreci açısından daha fazla etkili olacağını düşünmektedir. Diğer taraftan 10 yıl üstü ve altı bilgisayar kullanma tecrübesi olan öğretim elemanlarının, uzaktan eğitimin, değerlendirme açısından da Mann Whitney U testine göre istatistiksel olarak yine anlamlı farklılık tespit edilmiştir $(p<0,05)$. Teknoloji Kullanımı ve Destek Alma ve Derse Hazırlık ve Motivasyon açısından ise uzaktan eğitim sürecinin değerlendirilmesi yaşa göre anlamlı şekilde farklılaşmamaktadır. Bu boyutlarda öğretim üyelerinin puan ortalamaları birbirine yakın bulunmuştur $(\mathrm{p}>0,05)$.

\section{SONUÇ}

Literatür incelendiğinde uzaktan eğitime yönelik ulusal ve uluslararası düzeyde yapılmış pek çok çalışma olduğu görülebir (Özgöl ve diğerleri, 2017). Ancak son dönemde Covid-19 sürecinde, örgün eğitim içerisinde yürütülmeye başlanan uzaktan eğitim faaliyetlerini incelemeye yönelik yapılan çalışmalar, henüz az sayıda ve çok yenidir. Bir uygulama yeni olduğu zaman pek çok eksiklik ve problem yaşanabilir. Bu eksiklik ve problemlerin tespit edilmesi, çözüme ulaşmak için gereklidir. Bu konuda yapılacak olan çalışmalar örgün eğitim içerisinde uzaktan eğitim faaliyetlerinin kalitesini yükseltme açısından önemli görülmektedir. Ayrıca çalışmanın; öğretim elemanlarının görüşlerinden yola çıkarak, uzaktan eğitimde etkililiği ve verimliliği artıracak çalışmalara yol göstereceği de düşünülmektedir.

$\mathrm{Bu}$ araştırmada; öğretim programının temel ögelerine dayalı olarak oluşturulan anket kapsamında, öğretim elemanlarının görüşleri alınmıştır. Uygulanan anket sonucunda; öğretim, iletişim, teknoloji kullanımı destek ihtiyacı, değerlendirme gibi konularda, uzaktan eğitimde görev alan öğretim elemanlarının görüşlerinin temel anlamda önceki araştırmalardan çok farklılık göstermediği sonucu çıkarılabilmektedir.

Araştırmaya katılanların çoğu kadındır (\%60), araştırmaya katılanların yaş ortalaması 46,83 tür. Bilgisayar kullanma süreleri ise ortalama olarak 18,97 yıldır. 
Görüşlerine başvurulan akademisyenlerin, neredeyse tamamı uzaktan eğitimin uygulamalı eğitimde yararlı olamayacağını ifade etmişlerdir.

Teknolojik cihaz olarak çoğunlukla, eğitimde bilgisayar ve cep telefonu kullandıklarını belirtmişler ve kullanılan cihazın eğitimde etkisi olduğunu belirtenler çoğunluktadır (\%80). Yine çoğunlukla uzaktan eğitim verdikleri ortamda, bu eğitimi kullananların olduğu durumda bulunmaktadırlar. Öğretim elemanlarının yarıdan fazlası eşzamanlı ders vermektedirler. Araştırmaya katılanların \%60 a yakını sağlık bilimlerinde çalışan kişilerdir.

Araştırmaya göre; öğretim elemanlarının çoğunluğu teknolojik destek ve kullanılan yazılım konusunda sıkıntıları dile getirmektedir. Öğretim elemanları daha çok teknik desteğe ihtiyaç duymaktadırlar. Kullanılan yazılım programının eğitime etkisinin olduğunu düşünmektedirler ve çoğunlukla yazılım programından memnun değildirler (yaklaşık\% 85kararsızlarla birlikte). Oysa öğretim elemanlarının \%90 kadarı kullanılan programın eğitimin etkisini değiştireceği görüşündedir.

Tuncer ve Tanaş'ın bulgularına göre (2011), akademisyenlerin büyük çoğunluğu uzaktan eğitim konusunda bilgi sahibi olmakla birlikte, herhangi bir uzaktan eğitim uygulamasına katılmadıkları, görev yaptıkları üniversitelerin uzaktan eğitim konusunda bilgilendirici bir faaliyet planlamadığı anlaşılmaktadır. Aynı yüzdelik oranla akademisyenlerin uzaktan eğitim konusunda bireysel bir çaba sergilemediği de araştırma ile tespit edilen bir diğer konudur. Ancak pandemi sürecinde bu hazırlığın yapılması beklenemezdi.

Araştırmaya katılan öğretim elemanlarının derse hazırlık ve motivasyon konusundaki görüşlerinin en önemlisi, tamamı internetten ders vermeyi sevmemektedir. Yarıya yakını bu konuda kaygılıdır. Tamamına yakını derslere düzenli olarak hazırlandığını belirtmektedirler. Çoğunlukla derse motive olamadıklarını, öğrencileri motive edemediklerini ve öğrenciyle kolay iletişim kuramadıklarını belirtmektedirler. Sorumluluk içinde ders hazırlığı yaptıkları halde motivasyon konusundaki sorunlar dikkat çekicidir ve araştırılması gereken bir yandır. Teknik destekle birlikte, ders vermede kullanılabilecek uygun yollarla ilgili eğitimler yararlı olabilir.

Öğretim süreciyle ilgili ulaşılan bulgular sonucunda, katılanların \%42,7 si derslerde yeterince aktif olduğunu düşünmektedir. Yine aynı oranda kullandığı materyali yeterli bulmaktadırlar. Ancak çoğunluk materyal kullanmada yetersizlik bildirmektedir. \%75 oranda daha çok materyal kullanma gereği bildirilmektedir.

Katılanların neredeyse \%85'i eğitimde eksikliklerin olduğunu düşünmektedir ve laboratuvar ve grup çalışmaları gibi etkinliklerin yapılamadığını çoğunlukla belirtmektedir (\%76kararsızlarla birlikte). Ortamlarında kameranın var olmasından çoğunlukla rahatsız değildirler ve akranlarıyla konuşup tartışma eksiklilerini bildirmektedirler. \%75 oranda uzaktan eğitimin etkili bir yol olmadığını belirtmektedirler ((kararsızlarla birlikte). 
Görüşlerine başvurulan akademisyenlerin, neredeyse tamamı uzaktan eğitimin uygulamalı eğitimde yararlı olmadığını ifade etmişlerdir. Öğrencilerle kolay iletişim konusunda ise sadece \%21 oranında olumlu cevap alınmıştır. Öğretim elemanları öğrencilerle iletişimde zorluk çekmektedirler.

Tuncer ve Taşpınar (2007), uzaktan eğitimde kaliteli materyallerin hazırlanması, uygun öğrenme çevrelerinin yaratılması, iletişim ve sunu gibi öğretmen nitelikleri nedeniyle uzaktan eğitimde sorunlar yaşandığını belirtmiştir. Bu araştırmada da öğretim elemanları benzer sorunları yaşadıklarını belirtmişlerdir. Çalışmadan elde edilen sonuçlara göre, öğretim elemanları ders materyallerinin yeterli olmadığını düşünmektedirler.

Uzaktan eğitimde yapılan değerlendirmelerle ilgili olarak öğretim elemanları, yüz yüze eğitimden aldıkları verimi alamadıklarını düşünmektedirler (\%78 oranda). Nerdeyse tamamına yakını uygulamalı derslerde eksiklik yarattığını düşünmektedirler. Sadece \%20 oranda uzaktan eğitimde değerlendirmenin yapılabileceğini düşündükleri görülmektedir. Uzaktan eğitim yoluyla derslerin işlenmesinden memnun olanların oranı \%23'tür ve yaklaşık $\% 84$ 'te uzaktan eğitimden memnun değildirler. Sadece $\% 17,7$ si uzaktan eğitimin devam etmesini istemektedir. Ancak \%46 oranda da kendilerini geliştirdiğini düşünmektedirler.

Kullanılan teknolojik ortam (internet, yazılım programı vs.), uygulama süresi, öğretmen ve öğrencilerin şartları; uzaktan eğitimin etkinliğini değerlendirmede pratik ölçütler sağlayabilir. Kampüs eğitimine alternatif olarak uygulanan uzaktan eğitim; pandemi ve coğrafi nedenler, zaman kısıtlamaları ve mevcut tesis sınırlılıkları yüzünden sınıf öğretimiyle karşılaştırılabilir. $\mathrm{Bu}$ araştırmada öğretim elemanlarının çoğu yüz yüze eğitimdeki etkililiğin sağlanamadığını belirtmektedirler. Çünkü bu duruma pedagojik şartlar açısından hazır değillerdir ve bu durum pandemi için de tasarlanmış değildir.

$\mathrm{Bu}$ duruma göre, uygulanan uzaktan eğitimin biraz eksik kaldığı yorumu çıkarılabilir. Bu araştırmada. İşman'ın (2011, s. 744), sonuçlarına yakın bir sonuç ortaya çıkmıştır.

Cadlof ise bu süreçte (2020), birdenbire tüm eğitimin online olduğunu ve bu durumun çok büyük bir deneyim oluşturacağı görüşünü belirtmektedir (https://er.educause.edu/articles/2020/3/the-difference-between-emergency-remote-teachingand-online-learning).

Ulaşılan bulguların; şu anda uzaktan eğitim yapan kurumlara rehberlik edeceği, bu konuda çalışma yapacak olan araştırmacılara ışık tutacağı düşünülmektedir.

Hizmet içi eğitimlerle öğretim elamanlarının desteklenmesi ve uzaktan eğitim süresince geri bildirimler alınarak gerekli değişikliklerin yapılması da sunulan eğitimin kalitesini artıracaktır (Barış ve Çankaya,2016). Bu çalışma ile bu amaca katkı sağlandığı düşünülmektedir. 
Gürer ve diğerleri ulaştıkları bulgulardan biri; uzaktan eğitime hızlı geçişin uygun olmadığı ve olumsuz görüşler olduğudur (2016, s.15). Ancak pandemi döneminde böyle bir hazırlık mümkün olamamiştır.

İnternetin sunduğu olanaklar bu karşılaştırmalar için yeterli kanıtı sağlayamamaktadır. Bugün artık uzaktan eğitimin tasarlanması için, hangi pedagojik şartlar altında, hangi öğrencilerle, hangi içerik ve teknoloji medyasının kullanılmasıyla sağlandı̆̆ının bir bileşkesidir ve buna bakılmalıdır (Bernard ve diğgerleri, 2003).

Genel olarak bakıldığında uzaktan eğitim programlarının, akademisyen görüşlerine göre, henüz istenilen verimi sağlayamadığı söylenebilir. Bunun yanında uzaktan eğitim programları anlamında çalışma grubu kapsamındaki akademisyenlerin ve kurumların uzaktan eğitime hazır olmalarındaki eksikliklerin olduğu da söylenebilir. Bu bilgiler ışığında aşağıdaki öneriler geliştirilebilir;

-Akademisyenler uzaktan eğitim konusunda bilgilendirilmeli, bu yeni yaklaşımı tanımaları ve denemeleri konusunda teşvik edilmelidir Özellikle uygulamalı programlarda uzaktan eğitime yönelik bilgileri içeren eğitimler verilmelidir.

-Farklı öğretim yaklaşımları uzaktan eğitimde kullanılarak bulgular bilim dünyasıyla paylaşılmalıdır.

-Uzaktan eğitimin dezavantajlarını azaltmak için altyapı çalışmalarının öğretime başlamadan tamamlanması ve bu işle ilgili bir teknik ekip oluşturulması gerekli görülmektedir.

-Yaşanan gelişmeler göz önüne alındığında, zorunlulukla birlikte, disiplinler arası pragmatik bir alan olarak uzaktan eğitim uygulamalarında çeşitliliğin artacağı, yeni teknolojilerin entegrasyonu ile uzaktan eğitim süreçlerinin öğrenme içerik ve uygulamalarının daha da zenginleşeceği düşünülmektedir.

- Uzaktan eğitimde başarılı olunması için öğretenlerin yeni rollerinin farkına varması ve bu rollere uygun yeterlilik geliştirmeleri gereklidir (Berigel ve Çetin, 2018).

\section{KAYNAKÇA}

Bakioğlu, A. \& Can, E. (2014). Uzaktan eğitimde kalite ve akreditasyon. Ankara: Vize Yayıncllık.

Balta, Y., \& Türel, Y. K. (2013). Çevrimiçi uzaktan eğitimde kullanılan farklı ölçme değerlendirme yaklaşımlarına ilişkin bir inceleme. Turkish Studies-International Periodical For The Languages, Literature and History of Turkish or Turkic, 8(3), 37-45.

Beldarrain, Y. (2006). Distance education trends: Integrating new technologies to foster student interaction and collaboration. Distance Education, 27(2), 139-153.

Barış, M. F., \& Çankaya, P. (2016). Akademik personelin uzaktan eğitim hakkindaki görüşleri. International Journal of Human Sciences, 13(1), 399-413. doi:10.14687/ijhs.v13i1.3378 
Berigel, M. ve Çetin, İ. (2018) Uzaktan Ĕ̆itimde Öğreten ve Öğrenen Rolleri: Pegem Akademi

Bernard,R. M. 'Abrami, P.C.; Yiping,A., E. Borokhovski, A. Wade, L. Wozney,P. A.Wallet, and M. F.L.Yiping; Huangmesi.B.(2004). How Does Distance Education Compare With Classroom Instruction? A Meta-Analysis of the Empirical Literature. Review of Educational Research 74(3). DOI: $10.3102 / 00346543074003379$

Baggaley, J. (2008). Where did distance education go wrong? Distance Education, 29(1), 39-51. doi:10.1080/01587910802004837

Bolliger, D. U. \& Wasilik, O. (2009). Factors influencing faculty satisfaction with online teaching and learning in higher education. Distance Education, 30(1), 103-116. doi:10.1080/01587910902845949.

Bozkurt, A. (2017).Türkiye'de uzaktan eğitimin dünü, bugünü ve yarını. Açık Öğretim Uygulamaları ve Araştırmaları Dergisi (AUAd), 3(2), 85-124.

Cadlof,E.(2020).Uzaktaneğitimeilişkingörüşler.(https://er.educause.edu/articles/2020/3/the-differencebetween-emergency-remote-teaching-and-online-learning).

Dargut, T.,Torun,F, Erdem,M.(2016). Uzaktan eğitim araştırmaları üzerine kesitsel bir alan yazın incelemesi. AUAd 2016, Cilt 2, Sayı 1, 71-93.

Day, T.(2015).akademik süreklilik:ders kesintileri karşısındaki değerleri ve hedefleri öğrenmeye katmak https://www.cornell.edu/coronavirus/teaching-learning/students.cfm

Gülnar, B. (2008). Bilgisayar ve internet destekli uzaktan eğitim programlarının tasarım, geliştirme ve değerlendirme aşamaları (Suzep Örneği). Selçuk Üniversitesi Sosyal Bilimler Enstitüsü Dergisi. Sayı 19, s.259-273. oi:10.1080/01587919.2015.1055056

Gürer, M. D., Tekinarslan, E. \& Yavuzalp, N. (2016). Çevrimiçi ders veren öğretim elemanlarının uzaktan eğitim hakkındaki görüşleri. Turkish Online Journal of Qualitative Inquiry, 7(1), 47-78. doi:10.17569/tojqi.74876.

İşman, A. (2011). Uzaktan Eğitim. Ankara: Pegem Akademi Yayıncılık.

Kalaycı, Şeref. (2014). SPSS Uygulamahı Çok Değişkenli İstatistik Teknikleri. Ankara: Asil Yayıncılık.

Kaya,Z.(2004).Uzaktan Eğitim, Pegem Akademi.

McMillan, J. H. (1996). Educational Research: Fundamentals For The Consumer. New York: HarperCollins College Publishers.

Moore,,M.G.;G.,Kearsley(2012).Distance education:a systems view of online learning.3rd.ed.Belmont,CA:Wadsworth.engageLearning https://trove.nla.gov.au/version/175156294

Koloğlu, T. F., Kantar, M. \& Doğan, M. (2016). Öğretim elemanlarının uzaktan eğitimde hazırbulunuşluklarının önemi. Açıköğretim Uygulamaları ve Araştırmaları Dergisi, 2(1),52-70.

Kurubacak,G, ; A. Aydın; T. Görüf;, H.Yıldırım(2008) Öğretim elemanlarının uzaktan eğitime ilişkin görüşleri.

Menchaca, M. P. \& Bekele, T. A. (2008). Learner and instructor identified success factors in distance education. Distance Education, 29(3), 231-252. doi:10.1080/01587910802395771 
Özgöl,M., İ. Sarıkaya, M. Öztürk(2017). Örgün Eğitimde Uzaktan Eğitim Uygulamalarına İlişkin Öğrenci ve Öğretim Elemanı Değerlendirmeleri. DOI: 10.5961/jhes.2017.208

Simonson, M., Schlosser, C. \& Orellana, A. (2011). Distance education research: a review of the literature. Journal of Computing in Higher Education, 23, 124-142.

Tuncer, M. \& Tanaş, R. (2011). Akademisyenlerin uzaktan eğitim programlarına yönelik görüşlerinin değerlendirilmesi (Fırat ve Tunceli Üniversiteleri örneği). İlköğretim Online, 10(2), 776- 784. 6)

Turan, S. (2002). Teknolojinin Okul Yönetiminde Etkin Kullanımında Eğitim Yöneticisinin Rolü. Kuram ve Uygulamada Ĕ̆itim Yönetimi. Sayı: 30. 271-281.

Uşun, S. (2006). Uzaktan Eğitim. Ankara: Nobel Yayın Dağıtım.

Bu ararştırma; Üsküdar Üniversitesi Etik Kurulunun 27.05.2020 Tarihinde yapılan 07 No'lu toplantısında verilen izin çerçevesinde yapılan bir araştırmadır 
Altunizade Mahallesi Haluk Türksoy Sokak No:14 34662 Üsküdar/iSTANBUL T: 02164002222 F: 02164741256 bilgiduskudar.edu.tr

\section{T.C. \\ ÜSKÜDAR ÜNIVERSITESI \\ GIRIŞ̧IMSEL OLMAYAN ARAŞTIRMALAR \\ ETIK KURULU BAŞKANLIĞI}

SAYI: 61351342/ 2020-293

$27 / 05 / 2020$

\section{Sayın Dr.Öğr.Üyesi Hamiyet SAYAN}

Üsküdar Üniversitesi Girişimsel Olmayan Araştırmalar Etik Kurulunun 27/05/2020 tarihinde yapılan 07 no.lu toplantısında "COVID-19 Sürecinde Öğretim Elemanlarının Uzaktan Eğitime İlişkin Görüşlerinin Değerlendirilmesi” adlı araştırma projenizin etik
açıdan uygun olduğuna karar verilmiştir.

Bilgilerinize rica ederim.

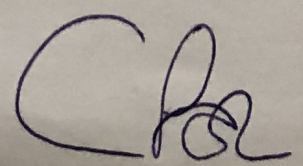

Doç. Dr. Cumhur TAȘ

Girişimsel Olmayan Araştırmalar Etik

Kurulu Başkanı 